\title{
Evaluation of Antimicrobial Potential of Some Indian Ayurvedic Medicinal Plants
}

\author{
Mrinmoy Nag, Pulok k Mukherjee *, Rajarshi Biswas, Joydeb Chanda, Amit Kar
}

Mrinmoy Nag,

Pulok k Mukherjee *, Rajarshi Biswas, Joydeb Chanda, Amit Kar

Department of Pharmaceutical Technology, Jadavpur University, Kolkata-700032, INDIA.

\section{Correspondence}

Pulok k Mukherjee, School of Natural Product Studies, Department of Pharmaceutical Technology, Jadavpur University, Kolkata700032, India.

Email: naturalproductm@gmail.com DOI : 10.5530/pj.2016.6.3

Article Available online http://www.phcogj.com/v8/i6

\section{Copyright}

(c) 2016 Phcog.Net. This is an openaccess article distributed under the terms of the Creative Commons Attribution 4.0 International license.

\begin{abstract}
Introduction: Stereospermum suaveolens Roxb., Viscum articulatum Burm., Annona squamosa, Capsicum annuum cayenne, Ananas comosus Merrill. are used for the management of microbial infection in Ayurveda. The present study was designed to standardize the extract of $S$. suaveolens bark (SSB), V. articulatum aerial part (VAAP), $A$. squamosa leaf (ASL), C. annuum fruit (CACF), A. comosus fruit (ACF) and performed antibacterial activity. Methods: The antibacterial activity of the five extracts were evaluated against certain bacteria such as B. subtilis, B. cereus, S. aureus (gram positive); E. coli, $S$. typhi, and P. aureugenosa (gram negative) by disc diffusion method, time course assay, $\mathrm{pH}$ sensitivity assay and minimum inhibitory concentration (MICs) through broth micro-dilution method. Results: The plants extracts VAAP, ASL, and CACF showed potent inhibitory activity against S. aureus with MIC 728, 742, and $698 \mu \mathrm{g} \mathrm{ml}^{-1}$, respectively, while CACF showed inhibitory activity against B. subtilis with MIC $690 \mu \mathrm{g} \mathrm{ml}^{-1}$. The results further demonstrated that the inhibitory activity of CACF against $E$. coli with MIC $760 \mu \mathrm{g} \mathrm{ml}^{-1}$. P. aeruginosa was inhibited by ASL and CACF with MIC 1100 and $1120 \mu \mathrm{g} \mathrm{ml}^{-1}$, respectively. The ASL showed notable MBC against the tested microorganism. Moreover, all extracts were completely inactivated bacterial strains (except B. cereus, S. typhi) within $2-10 \mathrm{~h}$ of exposure, determined by time course assay. Conclusion: The outcomes of our study elucidate that standardized extracts of $A$. comosus, A. squamosa, C. annuum, S. suaveolens, and $V$. articulatum may be used as natural antimicrobial agents.
\end{abstract}

Key words: Antibacterial, Ananas comosus Merrill, Annona squamosa, Capsicum annuum cayenne, Stereospermum suaveolens Roxb, Viscum articulatum Burm.

\section{INTRODUCTION}

The quest for new antimicrobial lead is a global challenge, as microbes are becoming resistant to the conventional antimicrobials as drug resistance is a natural phenomenon and microbes may develop resistance even without any exposure to a drug..$^{1-3}$ One way to overcome this problem of drug resistance is by developing new leads from natural resources. Now a day's many antibacterial agents are available, which are costly, have toxicity and yielded drugresistance mutants. Therefore, it needs to find cost effective readily available natural anti-microbial agents, with minimum side effects.

Stereospermum suaveolens Roxb. (Family: Bignoniaceae) is commonly known as Trumpet. Various parts of the plant are used in the treatment of diabetes, diuretic, pain, fever, inflammations, hiccup, leprosy and asthma. The root is used in the preparation of Ayurvedic formulation known as Dashmula. ${ }^{4-6}$ The plant bark contains sterekunthal $\mathrm{B}$, stereochenols A and B, lapachol, dehydro- $\alpha$-lapachone, apigenin. The major constituents are lapachol and apigenin have several pharmacological activities, including antimicrobial, antiviral, anti-inflammatory, antiparasitic, leishmanicidal and anticancer. ${ }^{7-8}$

Viscum articulatum Burm. (Family: Loranthaceae) is an ethnomedicinal plant are commonly known as mistletoe. . In Ayurveda, the plant parts are used in "Kapha", "Vata", diseases of the blood, ulcer, epilepsy and biliousness. ${ }^{10-11}$ The plant parts are also used in urinary tract infection, low back pain, dysentery, uterine bleeding and to treat weakness. ${ }^{9}$ The plant contains triterpenoids ( $\alpha$-amyrin, lupeol, betulin, betulinic acid and oleanolic acid). Among them betulinic acid, betulin and oleanolic acid exhibit antimicrobial activity. ${ }^{12}$

Annona squamosa (Family: Annonaceae) English name is custard apple, sugar apple or Sweetsop. The plant is traditionally used for the treatment of epilepsy. The plant is used in the treatment of dysentery, cardiac problems, worm infestation, cough, constipation, hemorrhage, diarrhoea, fever, thirst, bronchitis, helminthiasis, dropsy, painful malignant tumours and ulcers ${ }^{13}$ Ayurvedic practitioners use stem and leave extract as an indigenous 
uterotonic drug. The major active constituents of the leaves are anonaine, borneol, carvone, $\beta$-Caryphyllene, eugenol, farnesol, geraniol, higemamine, isocorydine, limonine, linalool acetate, menthone, $\alpha$-pinene, $\beta$-pinene, rutin, and gallic acid. ${ }^{14-16}$

Capsicum annuum (Family Solanaceae) is extensively used in food industry as natural flavouring and coloring agent and having more than 30 species. ${ }^{17-19}$ Among them Capsicum annuum cayenne one of the most popular species found in India. Capsicum has several therapeutic properties as topical analgesic, tonic, antiseptic, carminative and counters irritant property and also used for the treatment of inflammation, rheumatism, arthritis, neuralgia, itching, lumbago, spasms, obesity, cardiovascular and gastrointestinal diseases. The major active secondary metabolite found in capsicum fruit is capsaicin. Capsicum fruit contains healthpromoting metabolites, such as carotenoids, ascorbic acid (vitamin C), vitamin A and capsaicinoids ${ }^{19}$

Ananas comosus (L.) Merrill., (Family: Bromeliaceae) native to Central and South America, and can be found in Hawaii, Philippines, Caribbean, Malaysia, Thailand, Australia, Mexico, Kenya, South Africa and China. In China, the Pineapple cortexes were used as alexipharmic, antitussive and antidiarrheal agents. Juice of the leaves is used for the control of hiccoughs and vermifuge. The ripe pineapple fruit juice used as antiscorbutic, cholagogic, diaphoretic, refrigerant, and treatment of jaundice. ${ }^{20-21}$ The fruit juice contains ferulic acid, which is a phenolic acid having many activities, including antioxidant, antimicrobial, anti-inflammatory, anti-thrombosis, anti-cancer and anti-obesity activities. It also protects coronary disease, decreases cholesterol level and enhances sperm viability. $22-23$ Ample of evidences suggested that Stereospermum suaveolens Roxb., Viscum articulatum Burm., Annona squamosa, Capsicum annuum cayenne, Ananas comosus Merrill. are widely used in Ayurveda for treatment of microbial infection. The present study was designed for the evaluation of antimicrobial activity five plant extracts. Additionally, standardization has been performed by RP-HPLC to correlate the activity with phytoconstituents.

\section{MATERIALS AND METHODS}

\section{Chemicals and reagents}

All the chemicals and reagents were of analytical grade. Cell culture grade DMSO, HPLC grade of methanol, acetonitrile, water (Milli-Q) and glacial acetic acid were purchased from Merck Ltd. (Mumbai, India). Standard lapachol, apigenin, oleanolic acid, gallic acid, ferulic acid were purchased from Sigma Aldrich (St. Louis, MO, USA). Nutrient Agar (NA) and Muller Hinton Agar (MHA) obtained from Himedia, India. Ampicillin and streptomycin were purchased from Sisco Research Laboratory, India.

\section{Plant material collection and extraction}

The Stereospermum suaveolens bark (SSB), Viscum articulatum aerial part (VAAP), Annona squamosa leaf (ASL), Capsicum annuum cayenne fruit (CACF), Ananas comosus fruit (ACF) were collected from the North and South Bengal region in the month of December and July 2013. Further, collected plant sample was identified and authenticated by Dr. S. Rajan, Field Botanist, Survey of Medicinal Plants and Collection Unit, Emerald, Tamilnadu, India. After authentication, sample specimen was deposited in the Herbarium of the School of Natural Product Studies (SNPS), Jadavpur University, Kolkata, India for future reference. The vide voucher specimen number are SNPS-JU/2013/1462, SNPSJU/2013/1463, SNPS-JU/2013/1467 and SNPS-JU/2013/1468 for CACF, SSB, VAAP, ASL, respectively.

The plant SSB, VAAP, ASL, CACF were dried under shade and pulverized by using a mechanical grinder to make a coarse powder. Then powder was soaked in $95 \%$ methanol at room temperature $\left(25^{\circ} \mathrm{C}\right)$ for successive extraction. The whole extract was collected, filtered and the solvent was evaporated to dryness under reduced pressure and temperature $\left(45^{\circ} \mathrm{C}\right)$ by using Eyela Rotary Evaporator (Japan). The yield of methanol extract of SSB, VAAP, ASL and CACF was found to be $13.21 \%, 11.35 \%, 12.98 \%$ and $10.45 \%(\mathrm{w} / \mathrm{w})$ respectively. All dried methanol extract was stored at $4^{\circ} \mathrm{C}$ for further use.

The stalk (central core) of the pineapple (ACF) was separated from the fleshy fruits. The flesh of the fruit portion was then cut into small pieces and pulverized by using a mechanical grinder. The juice was filtered through a white cloth to remove the fibrous materials. The filtrate was centrifuged for $10 \mathrm{~min}$ to remove insoluble materials. The obtained clear supernatant was filtered again through what man filter paper. Further, the clear supernatant was lyophilized to make fine powder and stored at $-20^{\circ} \mathrm{C}$.

\section{HPLC analysis}

The HPLC system (Waters, Milford, MA, USA) used for the analysis was equipped with a 600-controller pump, a multiple-wavelength ultravioletvisible (UV-Vis) detector equipped with an in-line degasser AF2489 and a Rheodyne 7725i injector having $20 \mu$ loop. Quantitative estimation was performed with Empower 2 software programs using the external calibration method. Membrane filters of $0.45 \mu \mathrm{m}$ pore size (Millipore) were used for filtration of the mobile phase and $0.45 \mu \mathrm{m}$ syringe filters (NYL) were used for the filtration of the sample.

\section{Antibacterial assay}

Preparation of stock solution of antibiotic, plant extracts and their biomarkers

Stock solution of ampicillin and streptomycin (Sisco Research Laboratory, India) were used as a concentration of $10 \mu \mathrm{g} / \mathrm{ml}(\mathrm{w} / \mathrm{v})$. DMSO $1 \%(\mathrm{v} / \mathrm{v})$ was used as solubilizing solvent for test samples and also used as control to evaluate the antibacterial assay. Stock solution of individual plant extracts (Stereospermum suaveolens, Viscum articulatum, Annona squamosa, Capsicum annuum cayenne and Ananus comosus) were prepared and the final concentration of each plant extract was $5000 \mu \mathrm{g} \mathrm{ml}^{-1}$, freshly prepared stock solution and requisite different concentration for the bacterial tests were prepared from this stock solution.

\section{Bacterial strains and culture condition}

Gram positive (Bacillus subtilis ATCC 11774, Bacillus cereus ATCC 14579, Staphylococcus aureus ATCC 29213), and gram negative (Escherichia coli ATCC 25922, Salmonella typhi MTCC 734, and Pseudomonas aureugenosa ATCC 9027) bacteria were selected as standard strains as per the guidelines of the Clinical and Laboratory Standards Institute (CLSI), formerly called National Committee for Clinical Laboratory Standards ${ }^{24}$ For experimental purpose bacterial cultures were maintained on Nutrient Agar (NA) or Nutrient Broth (NB) (Himedia, Mumbai, India) at $4^{\circ} \mathrm{C}$ and subculture in every 4 weeks.

\section{Disc diffusion method}

The antibacterial assay of crude extracts and their biomarkers were performed by disc diffusion method. ${ }^{24}$ Concisely, $10 \mathrm{ml}$ of sterilized Muller Hinton Agar (MHA) ( $\mathrm{pH} 7.2 \pm 0.2$, at $25^{\circ} \mathrm{C}$ ) were applied in to the surface of sterile Petri dishes $(9 \mathrm{~cm}$ in diameter, Borosil) and allowing them to settle for base plate preparation. $100 \mathrm{ml}$ of test bacterial suspension $\left(5 \times 10^{5} \mathrm{CFU} / \mathrm{ml}\right)$ were poured to each base plate and cotton swab (Himedia). $20 \mathrm{ml}$ of different concentrations of each test sample $(50-2000 \mathrm{mg} / \mathrm{disc})$ were soaked with sterile paper discs $(6 \mathrm{~mm})$. The air-dried discs were placed on each base plate and incubated at $37 \pm 2^{\circ} \mathrm{C}$ for $24 \mathrm{~h}$. Ampicillin and streptomycin were used in $20 \mathrm{mg} /$ disc concentration range as positive control for gram negative and gram positive microorganisms respectively. The inhibition of zones around the discs was determined as the diameter $(\mathrm{mm})$ of bacterial growth inhibition. The zone of inhibition 
was taken as an average of three measurements at different directions. ${ }^{25}$ All experiments were performed in triplicate.

\section{Determination of minimum inhibitory concentration (MICs) and minimum bactericidal concentration (MBCs)}

MICs values were determined by broth micro-dilution method suggested by the CLSI. ${ }^{24}$ Briefly, microbial cultures were prepared by suspending one isolated colony from each base plate in $5 \mathrm{ml}$ of MHB. After $24 \mathrm{~h}$ of proper incubation period, the suspensions were diluted in to get the final inoculum population $\left(5 \times 10^{5} \mathrm{CFU} / \mathrm{ml}\right)$ by using to $0.5 \mathrm{Mac}$ Farmland standard. Colony morphology and gram stain procedure were adopted for checking of accuracy of mother culture throughout the test. 96-well microtiter plates were used for two fold serial dilutions of test samples using known stock solution with MHB. An equal volume of bacterial inoculums was added to each well on the microtiter plate consist of $0.05 \mathrm{ml}$ of serial dilutions of compound which was incubated at $37 \pm 2^{\circ} \mathrm{C}$ for $24 \mathrm{~h}$. MICs values were defined as the lowest concentration of substance that inhibits visible growth of bacteria in media. Bacterial growth was displayed by the presence of turbidity and a pellet on the well bottom. MICs were determined presumptively as the first well, where no pellet appeared. ${ }^{26}$ It was calculated by comparing the absorbance of sample wells with the control wells with the help of Spectra-max M5 (USA) at $405 \mathrm{~nm}$ wavelengths. The MBC was determined by adding $50 \mu \mathrm{l}$ of the suspensions from the wells in $25 \mathrm{ml}$ fresh MHB. These suspensions were re incubated at $37^{\circ} \mathrm{C}$ for $48 \mathrm{~h}$. The $\mathrm{MBC}$ was determined as the lowest concentration of extract which inhibited the complete growth (100\%) of microorganisms.

\section{pH sensitivity assay}

The effect of $\mathrm{pH}$ on antibacterial activity of the plant extract was determined by $\mathrm{pH}$ sensitivity assay. ${ }^{27}$ Overnight the broth cultures of B. subtilis, B. cereus, S. aureus, E. coli, S. typhi, and P. aureugenosa with different $\mathrm{pH}$ range $(5.5,6.0,6.5,7.0,7.5,8.0,8.5$, and 9.0) were prepared by using $0.1 \mathrm{~N} \mathrm{HCl}$ and $5 \mathrm{M} \mathrm{NaOH}$ and swabbed on MHA plates with the corresponding $\mathrm{pH}$. The antibacterial activity was analyzed by discdiffusion method. Ampicillin and streptomycin were used as positive control for gram negative and gram positive bacteria, respectively.

\section{Time course assay}

The rapidity and duration of antibacterial activity was determined by time-kill analysis. ${ }^{28}$ Overnight broth cultures of bacterial strains were adjusted to the concentration of $5 \times 10^{5} \mathrm{CFU} / \mathrm{ml}$ and were treated with plant extracts $(\mathrm{MIC} \times 2)$. Control tubes were also prepared without plant extract. Then $100 \mu \mathrm{l}$ of sample was taken and plated on MHA plates at regular time intervals $(0,1 \mathrm{~h}, 2 \mathrm{~h}, 4 \mathrm{~h}, 6 \mathrm{~h}, 8 \mathrm{~h}, 10 \mathrm{~h}$ and $12 \mathrm{~h})$. The plates were incubated at $37^{\circ} \mathrm{C}$ for $24 \mathrm{~h}$ and $\mathrm{CFU}$ was calculated. All the determinations were done in triplicates.

\section{Statistical analysis}

Data expressed as mean Inhibition zone diameter \pm SEM. The results recorded were statistically analyzed by one way ANOVA using GraphPad InStat Version 5.0 (GraphPad Software, Inc., USA).

\section{RESULTS AND DISCUSSION}

\section{Determination of selected phytomarkers in plant extract by RP-HPLC method}

The mean $\mathrm{R}_{\mathrm{t}}$ was observed, $7.96 \pm 0.06$ (for lapachol), $6.34 \pm 0.06$ (for apigenin), $21.5 \pm 0.04$ (for oleanolic acid), $11.23 \pm 0.05$ (for gallic acid), $5.11 \pm 0.03$ (for capsaicin), $5.83 \pm 0.05 \mathrm{~min}$ (for ferulic acid) by comparing between standard and extract chromatograms. Chromatograms has been represented in supplementary file (1S-10S). The calibration range of lapachol, apigenin, oleanolic acid, gallic acid, capsaicin and ferulic acid was found to be $10-100,1-80,10-800,10-1000,1-80,1-100 \mu \mathrm{g} / \mathrm{ml}$ respectively, with the linear equation $\mathrm{Y}=26513 \mathrm{X}+62826, \mathrm{Y}=23838 \mathrm{X}+$ $58264, Y=19462 X+16172, Y=51474 X+13792$ and $Y=83252 X+10246$ with coefficient of determinants $\left(\mathrm{r}^{2}\right)$ of $0.996,0.993,0.995,0.996$ and 0.994 respectively. The amount of lapachol and apigenin, oleanolic acid, gallic acid, capsaicin and ferulic acid found in SSB, VAAP, ASL, CACF and $\mathrm{ACF}$ was $1.42 \%$ and $0.46 \%, 1.96 \%, 0.50 \%, 3.12 \%, 1.05 \% \quad(\mathrm{w} / \mathrm{w})$, respectively.

\section{Antibacterial activity \\ $M I C$ and $M B C$ of plant extracts}

Five plant extract tested against six bacterial (E. coli, S. aureus, B. subtilis, S. typhi, B. cereus, P. aeruginosa) strains showed significant inhibitory activity with MIC bellow $2000 \mu \mathrm{g} \mathrm{ml}^{-1}$ (Table 1). All the five plant, SSB, VAAP, ASL, CACF and ACF showed inhibitory activity against $S$. aureus with MIC 935, 728, 742, 698, $892 \mu \mathrm{g} \mathrm{ml}^{-1}$ (Table 1), while ASL and CACF showed inhibitory activity against bacterial strains (B. subtilis) with MIC 812 and $690 \mu \mathrm{g} \mathrm{ml}^{-1}$ respectively (Table 1 ). The results further demonstrated that the inhibitory activity of VAAP, ASL, CACF and ACF against E. coli with MIC 920, 802, 760 and $792 \mu \mathrm{g} \mathrm{ml}^{-1}$, respectively. Where as ASL and CACF inhibited gram negative bacterial strain (P. aeruginosa) with MIC 1100 and $1120 \mu \mathrm{g} \mathrm{ml}^{-1}$ (Table 1) respectively. Hence, the results indicated that CACF showed potent $(15.2 \mathrm{~mm})$ antibacterial activity against $S$. aureus. Whereas, the SSB, VAAP, ASL, CACF and ACF plant extract possesses moderate to poor degree $(10-15 \mathrm{~mm})$ of antibacterial activity against 3 strains $S$. aureus, B. subtilis, E. coli. While $S$. aureus, $P$. aeruginosa had weak activity $(7-10 \mathrm{~mm})$. The $\%$ inhibition of the SSB, VAAP, ASL, CACF and ACF against the tested bacterial strains are shown in Figure 1 (A-E). The minimal bactericidal concentration assay, using 2- to 3-fold MIC, presented that at lower concentrations of the plant extract had bacteriostatic activity, but at higher concentrations had bacteriocidal activity (Table 2), due to the presence of one or more active principle in the extract.

\section{Table 1: Zone of inhibition and MIC value of the plant extracts}

\begin{tabular}{|c|c|c|c|c|c|c|c|c|c|c|c|c|}
\hline \multirow{3}{*}{$\begin{array}{c}\text { Name of the plant } \\
\text { extract }\end{array}$} & \multicolumn{12}{|c|}{ Name of the Bacteria } \\
\hline & \multicolumn{2}{|c|}{ S. aureus } & \multicolumn{2}{|c|}{ B. subtilis } & \multicolumn{2}{|c|}{ B. cereus } & \multicolumn{2}{|c|}{ E. coli } & \multicolumn{2}{|c|}{ S. typhi } & \multicolumn{2}{|c|}{$P$. aeruginosa } \\
\hline & $\begin{array}{c}\text { MIC } \\
\left(\mu \mathrm{gml}^{-1}\right)\end{array}$ & $\begin{array}{l}\text { ZOI } \\
(\mathrm{mm})\end{array}$ & $\begin{array}{c}\text { MIC } \\
\left(\mu \mathrm{gml}^{-1}\right)\end{array}$ & $\begin{array}{c}\mathrm{ZOI} \\
(\mathrm{mm})\end{array}$ & $\begin{array}{c}\text { MIC } \\
\left(\mu \mathrm{gml}^{-1}\right)\end{array}$ & $\begin{array}{l}\text { ZOI } \\
(\mathrm{mm})\end{array}$ & $\begin{array}{c}\text { MIC } \\
\left(\mu \mathrm{gml}^{-1}\right)\end{array}$ & $\begin{array}{c}\text { ZOI } \\
(\mathrm{mm})\end{array}$ & $\begin{array}{c}\text { MIC } \\
\left(\mu \mathrm{gml}^{-1}\right)\end{array}$ & $\begin{array}{l}\mathrm{ZOI} \\
(\mathrm{mm})\end{array}$ & $\begin{array}{c}\text { MIC } \\
\left(\mu \mathrm{gml}^{-1}\right)\end{array}$ & $\begin{array}{l}\mathrm{ZOI} \\
(\mathrm{mm})\end{array}$ \\
\hline S. suaveolens & 935 & $9.2 \pm 0.02$ & - & - & - & - & - & - & - & - & - & - \\
\hline V. articulatum & 728 & $11.4 \pm 0.05$ & - & - & - & - & 920 & $10.1 \pm 0.06$ & - & - & - & - \\
\hline A. comosus & 892 & $8.2 \pm 0.05$ & - & - & - & - & 792 & $13.1 \pm 0.04$ & - & - & - & - \\
\hline
\end{tabular}


Table 2: MBC value of the plant extracts

\begin{tabular}{cccccccc}
\hline S.l. No. & Plant extract & \multicolumn{5}{c}{ Bacteria MBC $\left(\mu \mathrm{g} \mathrm{ml}^{-1}\right)$} \\
\cline { 3 - 7 } & & S. aureus & B. subtilis & B. cereus & E. coli & S. typhi & P. aeruginosa \\
\hline 1 & S. suaveolens & 1870 & - & - & - & - & - \\
2 & V. articulatum & 1456 & - & - & 1840 & - & - \\
3 & A. squamosa & 1484 & 1624 & - & 1604 & - & 2200 \\
4 & C. annuum cayenne & 2094 & 2070 & - & 2280 & - & 3360 \\
5 & A. comosus & 2230 & - & - & 1980 & - & - \\
\hline
\end{tabular}

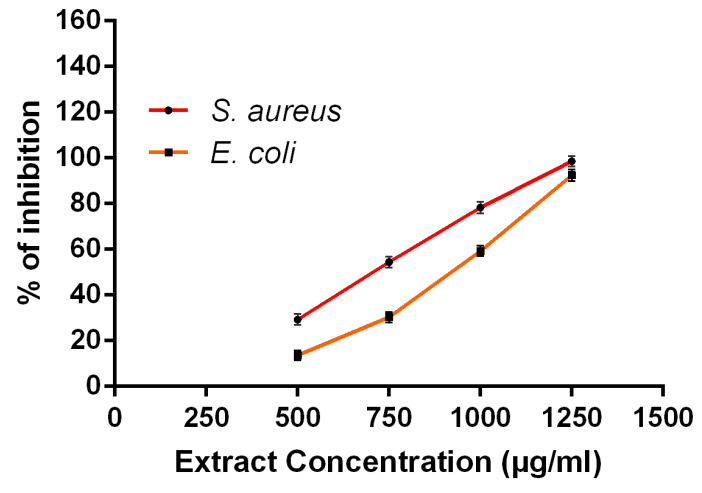

Figure 1A

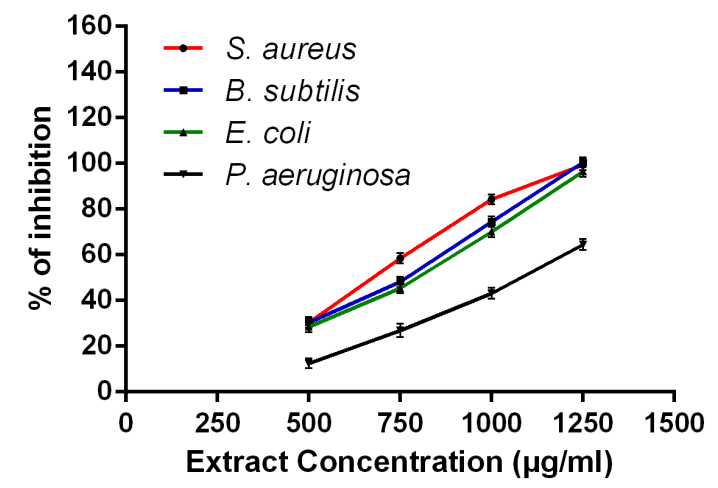

Figure 1C

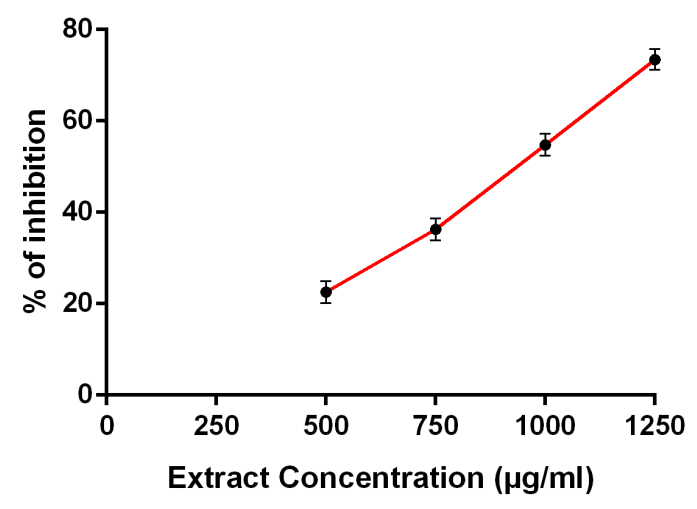

Figure 1 B

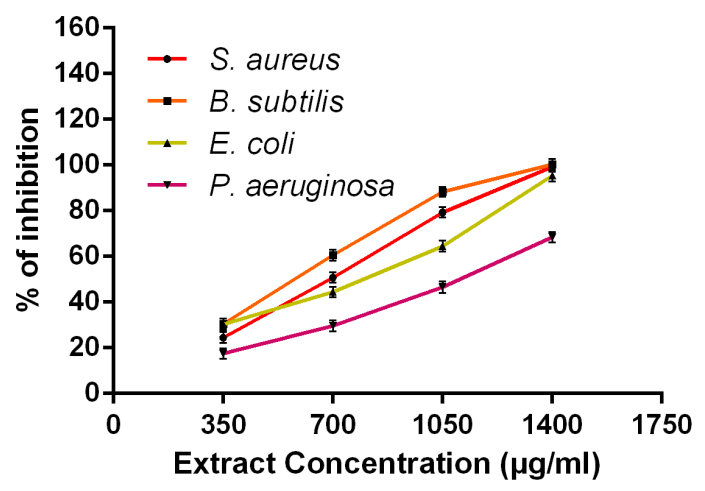

Figure 1D

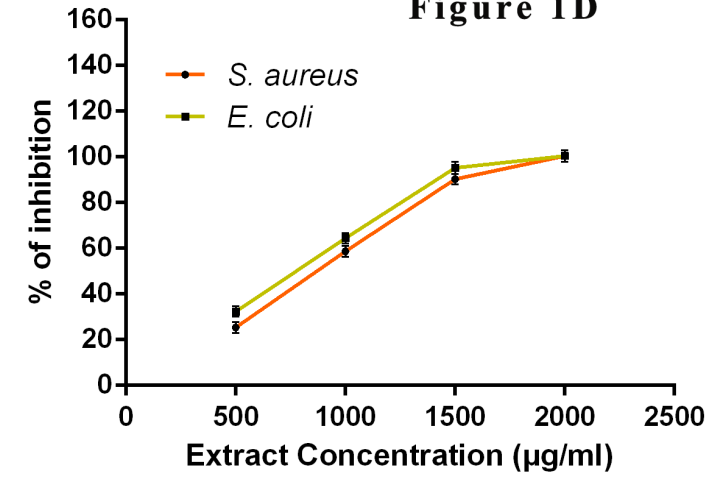

Figure 1 E

Figure $1 \mathrm{~A}$ : Percentage of inhibition curve of Viscum articulatum extract.

Figure 1B : Percentage of inhibition curve of Stereospermum suaveolens extract.

Figure 1C : Percentage of inhibition curve of Annona squamosa extract.

Figure 1D : Percentage of inhibition curve of Capsicum annuum cayenne extract.

Figure 1E : Percentage of inhibition curve of Ananas comosus extract. 

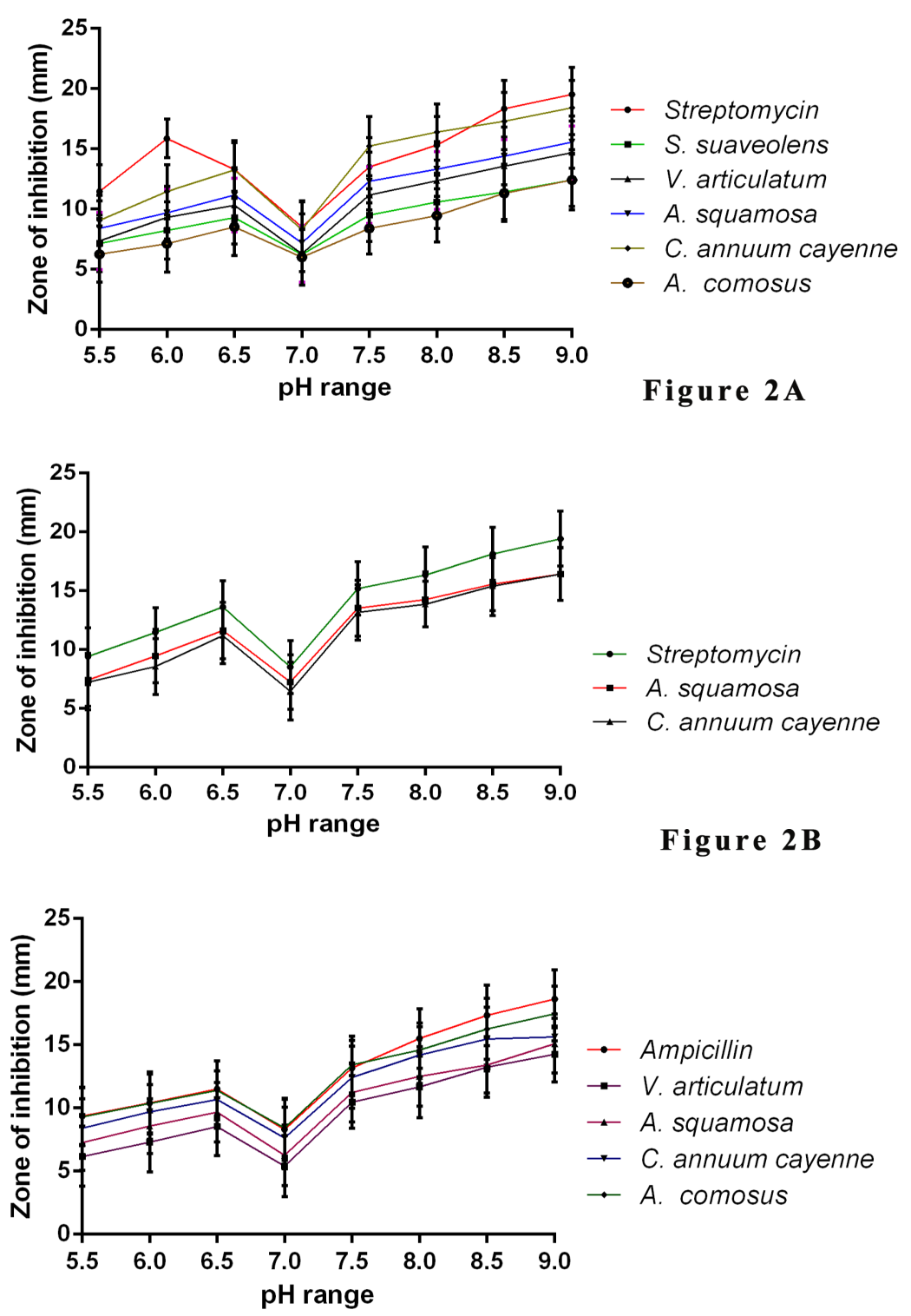

Figure 2C

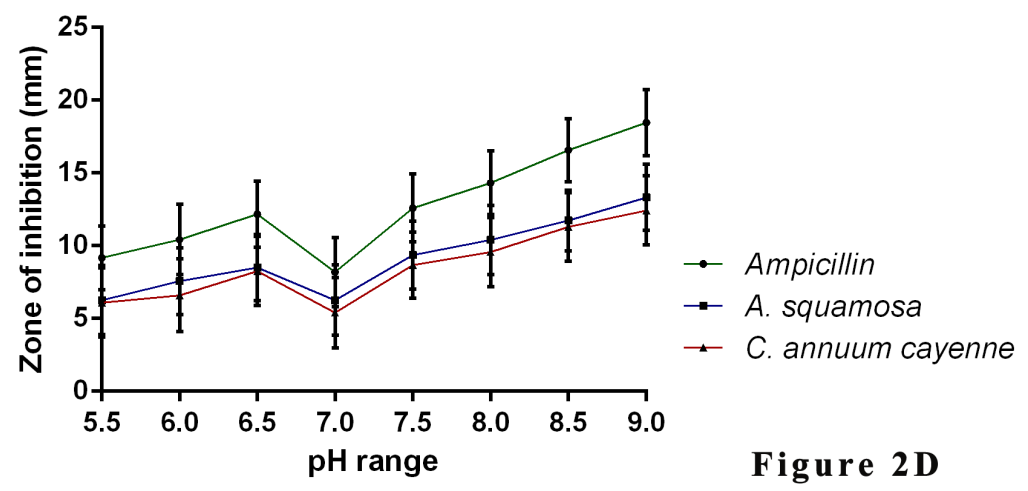

Figure 2A : Effect of $\mathrm{pH}$ against Staphylococcus aureus.

Figure 2B : Effect of $\mathrm{pH}$ against Bacillus subtilis.

Figure $2 \mathrm{C}$ : Effect of $\mathrm{pH}$ against Escherichia coli.

Figure 2D : Effect of $\mathrm{pH}$ against Pseudomonas aureugenosa. 

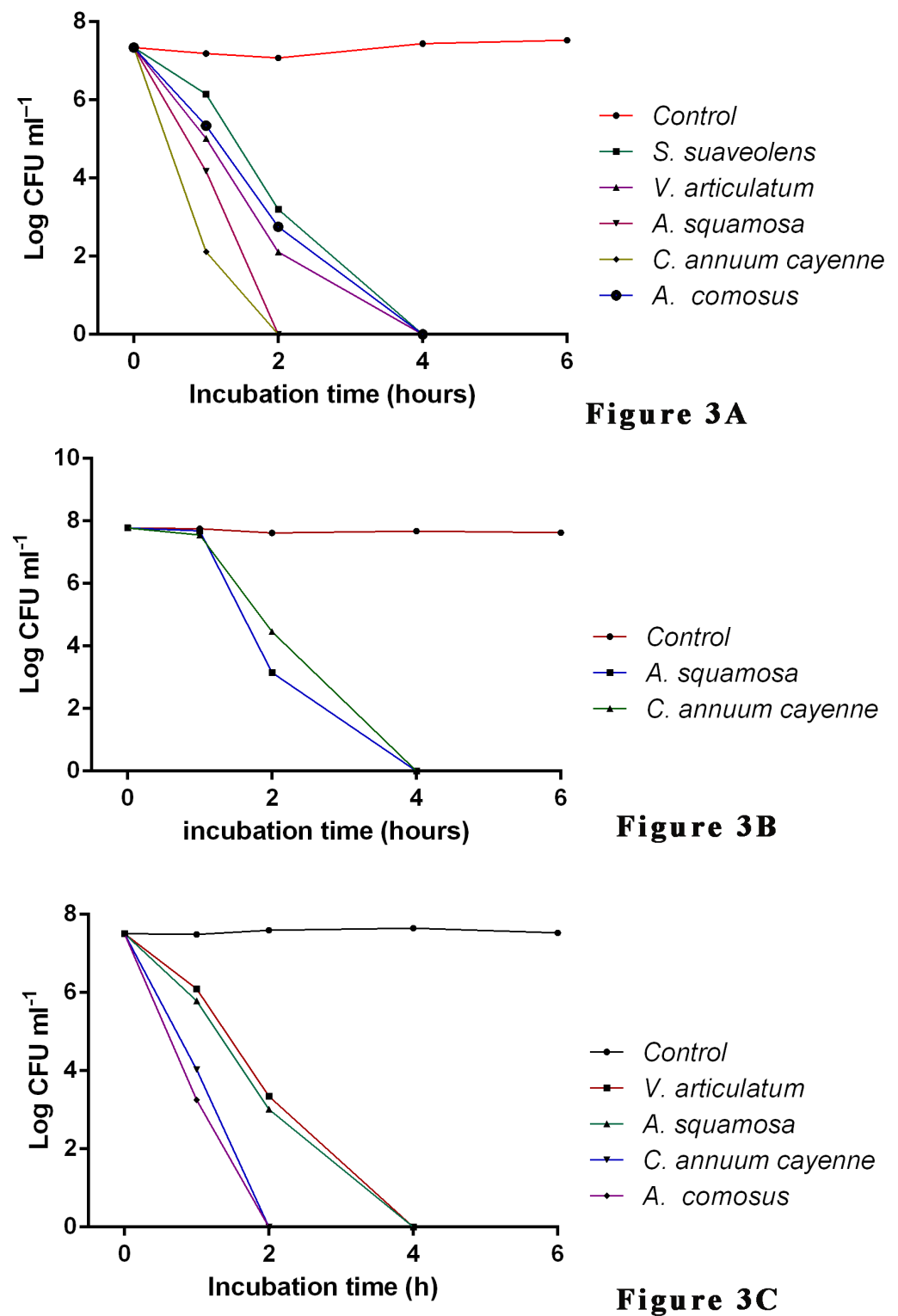

$\rightarrow$ Control

$\rightarrow$ V. articulatum

$\rightarrow$ A. squamosa

$\rightarrow$ C. annuum cayenne

$\rightarrow$ A. comosus

\section{Figure 3C}

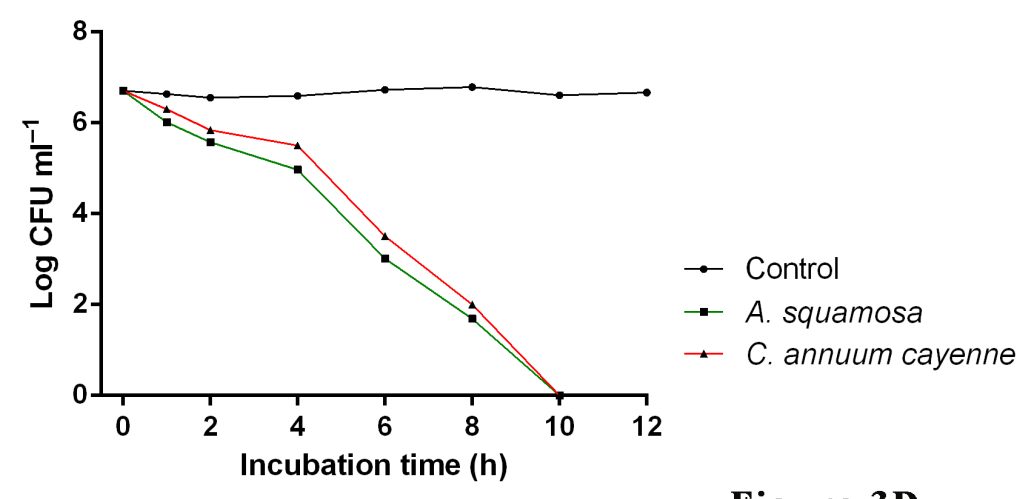

Figure 3D

Figure 3A : Time course assay of the plant extracts on Staphylococcus aureus.

Figure 3B : Time course assay of the plant extracts on Bacillus subtilis.

Figure $3 \mathrm{C}$ : Time course assay of the plant extracts on Escherichia coli.

Figure 3D : Time course assay of the plant extracts on Pseudomonas aureugenosa. 


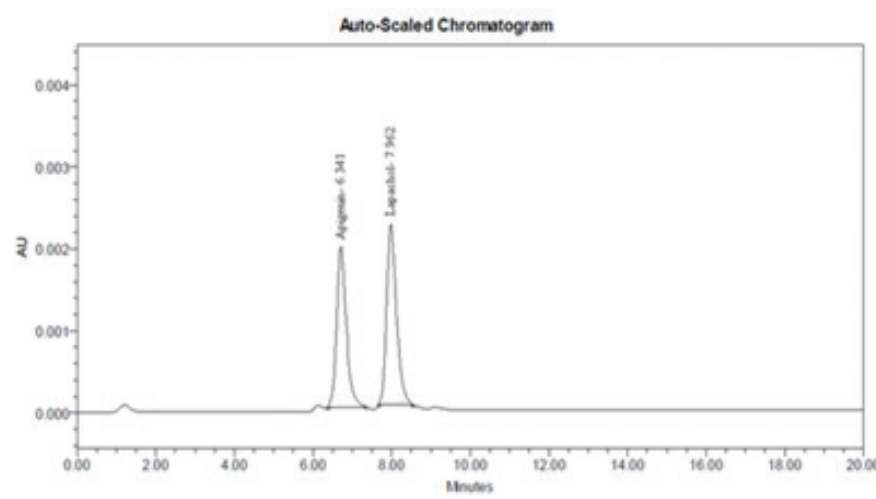

Figure 1S : RP-HPLC chromatogram of Lapachol and Apigenin

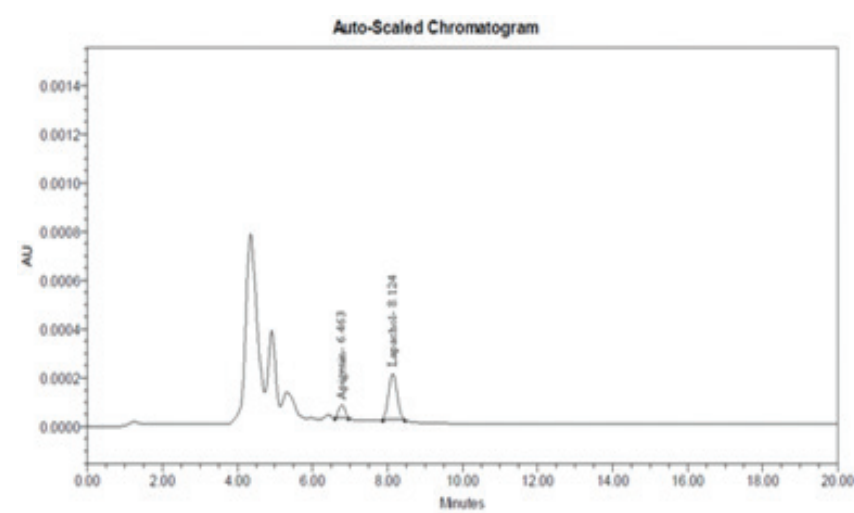

Figure 2S : RP-HPLC chromatogram of Stereospermum suaveolens extract

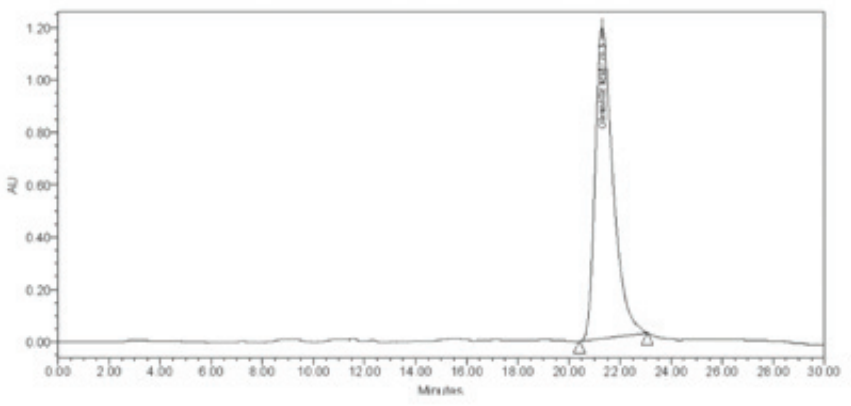

Figure 3S : RP-HPLC chromatogram of Oleanolic acid

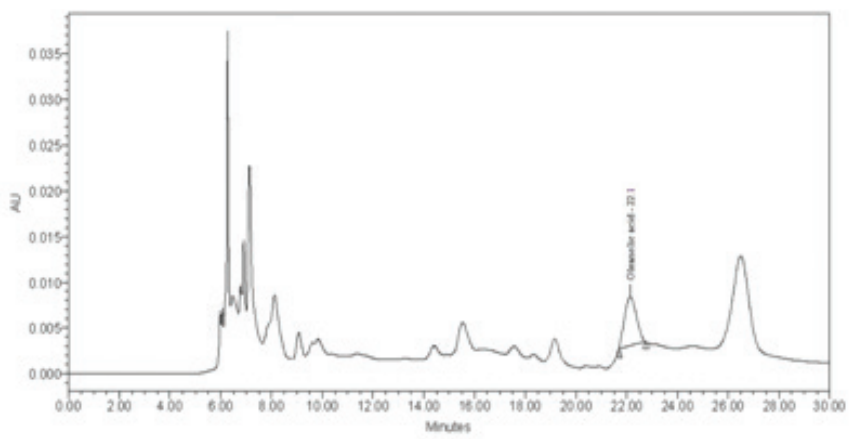

Figure 4S : RP-HPLC chromatogram of Viscum articulatum extract

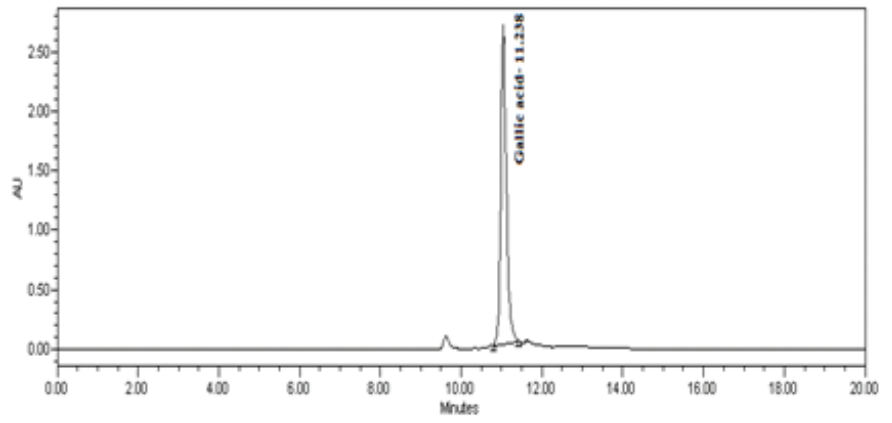

Figure 5S : RP-HPLC chromatogram of Gallic acid

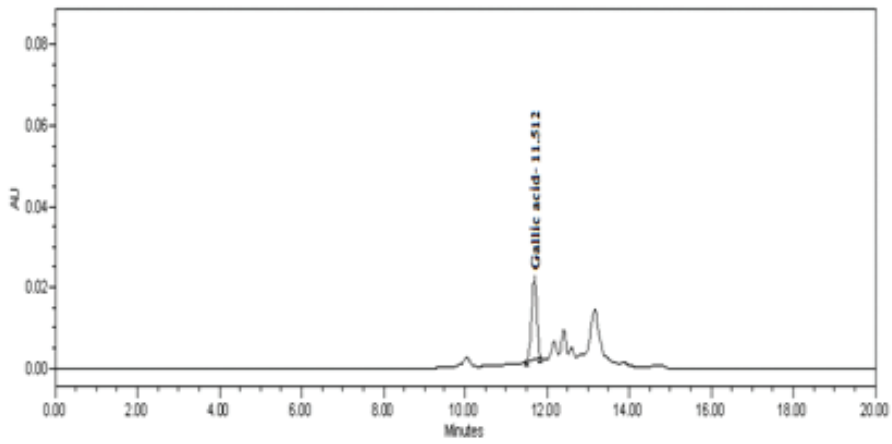

Figure $6 \mathrm{~S}: \mathrm{RP}-\mathrm{HPLC}$ chromatogram of Annona squamosa extract

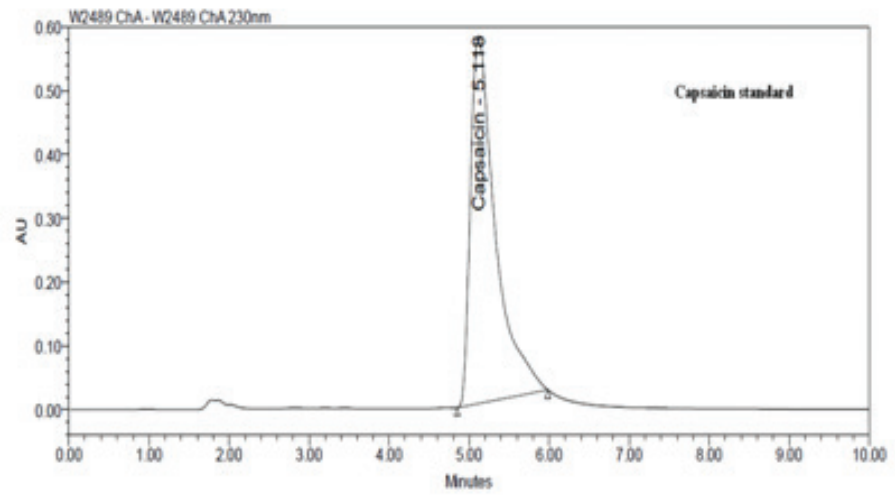

Figure 7S : RP-HPLC chromatogram of Capsaicin

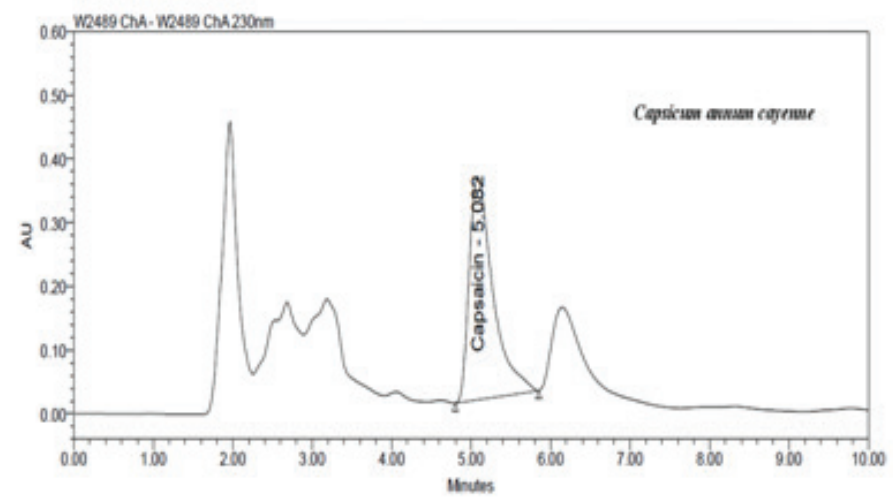

Figure $8 \mathrm{~S}: \mathrm{RP}-\mathrm{HPLC}$ chromatogram of Capsicum annuum cayenne extract 


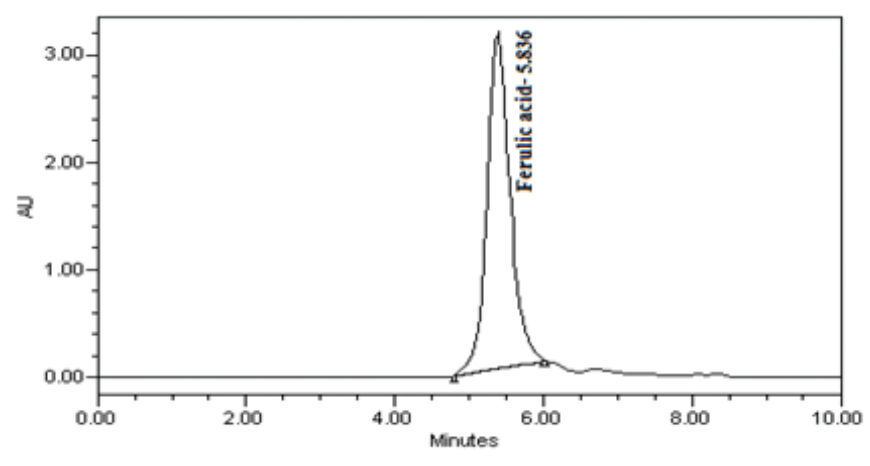

Figure 9S : RP-HPLC chromatogram of Ferulic acid

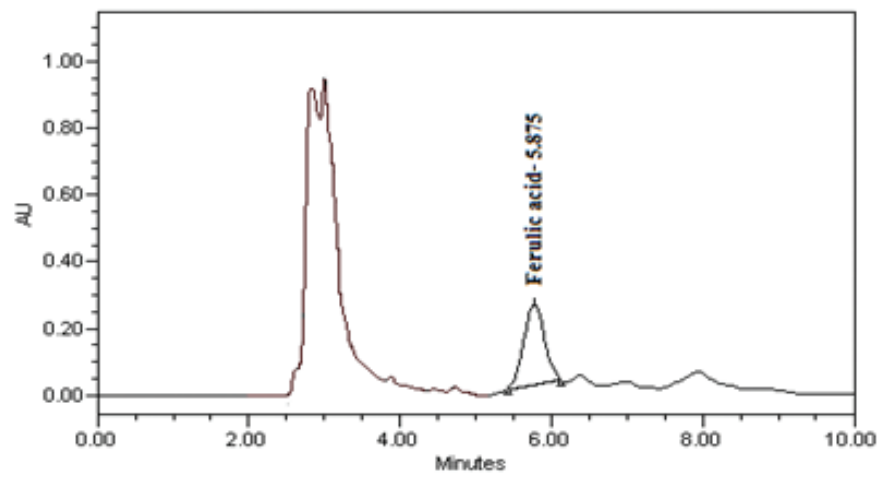

Figure 10S : RP-HPLC chromatogram of Ananas comosus extract

\section{Effect of $\mathrm{pH}$ on the antibacterial activity}

The antibacterial activity of plant extracts increased gradually with increasing the $\mathrm{pH}$ of the medium. The highest zone of inhibition $(18.4 \mathrm{~mm})$ against $S$. aureus was observed at $\mathrm{pH} 9$ with $C$. annuum cayenne extract (Figure 2A). The effect of $\mathrm{pH}$ on inhibition zone of the plant extracts against $S$. aureus, B. subtilis, E. coli, P. aeruginosa are shown in Figure 2 (A-D). The growth of bacteria in the control discs loaded with DMSO, unaffected by the changes in $\mathrm{pH}$. In case of Ampicillin and Streptomycin both are showed highest zone of inhibition $18.6 \mathrm{~mm}$ and $19.5 \mathrm{~mm}$ respectively, at $\mathrm{pH} 9$ compared with other $\mathrm{pH}$ ranges.

Time course assay

Treatment with S. suaveolens, V. articulatum, A. squamosa, C. annuum cayenne and $A$. comosus extracts (MBC) exhibited bactericidal effect on the test organisms. Out of five plants extracts A. squamosa and C. annuum cayenne completely inactivated $S$. aureus and B. subtilis population within $2 \mathrm{~h}$ and $4 \mathrm{~h}$ (Figure $3 \mathrm{~A}$ and $3 \mathrm{~B}$ ), respectively. Whereas S. suaveolens, V. articulatum and A. comosus inactivated S. aureus population within $4 \mathrm{~h}$ (Figure 3A). In case of E. coli, the two plant extracts ( $V$. articulatum and $A$. squamosa) completely inactivated bacterial population within $4 \mathrm{~h}$ and other two plant extracts (C. annuum cayenne and A. comosus) inactivated bacterial population within $2 \mathrm{~h}$ (Figure 3C). While, A. squamosa and C. annuum cayenne completely inactivated $P$. aeruginosa population with in $10 \mathrm{~h}$ (Figure $3 \mathrm{D}$ ). These results suggest that the studied plant extracts completely reduces the reproducing capability of bacterial strains (S. aureus, B. subtilis, E. coli, P. aeruginosa) within 2-10 h of exposure (Figure 3A-3D).

\section{CONCLUSION}

The results of the experiments clearly suggested that A. comosus, A. squamosa, C. annuum, S. suaveolens, $V$. articulatum extracts has potential anti- bacterial agents against S. aureus, B. subtilis, E. coli and P. aeruginosa. A. squamosa, and $C$. annuum possessed most potent antimicrobial activity among the five tested plant extract. This scientific exploration will help to identify effective antimicrobial agents from medicinal plants, which may be clinically investigated for the treatment of infectious diseases.

\section{ACKNOWLEDGEMENT}

The authors are thankful to Jadavpur University for providing the opportunity to carry on Research work.

\section{CONFLICT OF INTEREST}

The authors declare that they have no conflict of interest.

\section{REFERENCES}

1. Latha PS, Kannabiran K. Antimicrobial activity and phytochemicals of Solanum trilobatum Linn. Afr J Biotechnol. 2006;5(23):2402-4.

2. Olofsson SK, Cars O. Optimizing drug exposure to minimize selection of antibiotic resistance. Clin Infect Dis. 2007;45(Supplement 2):129-36. http://dx.doi. org/10.1086/519256. PMid:17683017.

3. Galan JC, Gonzalez-Candelas F, Rolain JM, Canton R. Antibiotics as selectors and accelerators of diversity in the mechanisms of resistance: from the resistome to genetic plasticity in the b-lactamases world. Front Microbiol. 2013;4:1-17. http://dx.doi.org/10.3389/fmicb.2013.00009. PMid:23404545 PMCid:PMC3567504

4. Thirumalaisamy B, Prabhakaran GS, Marimuthu K, Chatterjee TK. Antihyperlipidemic activity of the ethyl-acetate fraction of Stereospermum suaveolens in streptozotocin-induced diabetic rats. J Pharmacopun. 2013;16(3):23-9. http:// dx.doi.org/10.3831/KPI.2013.16.020 . PMid:25780672 PMCid:PMC4331969.

5. Nadkarni KM. Indian Materia Medica. Bombay: Popular Prakashan, 1976;1:1142.

6. Shukla S, Shukla SK, Mishra SK. In vitro regeneration of multipurpose medicinal tree Stereospermum suaveolens-factors controlling the in vitro regeneration. J Biotechnol Biomater. 2012;13:1-3.

7. Hussain H, Krohn K, Ahmad VU, Miana GA, Green IR. Lapachol: an overview. Arkivoc. 2007;2:145-71.

8. Tago MF, Nakamura K, Tago K, Mashino T, Kasahara T. Anti-inflammatory activity of structurally related flavonoids, apigenin, luteolin and fisetin. Int Immunopharmacol. 2011;11(9):1150-9. http://dx.doi.org/10.1016/j.intimp.2011.03.012. PMid:21443976.

9. Tripathi S, Ray S, Mondal AK, Verma NK. Rare ethno medicinal plants of south West Bengal, India with their different medicinal uses: needs conservation. Int J LifeSc Bt \& Pharm Res. 2013;2(2):114-22.

10. Kulkarani DK, kumbhojkar MS. Traditional use of Family Loranthaceae from western Maharastra, India. Anc Sci Life. 2002;21(3):178.

11. Kirtikar KR, Basu BD. Indian Medicinal Plants. Dehradun, India. 1987.

12. Horiuchi K, Shiota S, Hatano T, Yoshida T, Kuroda T, Tsuchiya T. Antimicrobial activity of oleanolic acid from Salvia officinalis and related compounds on vancomycin-resistant enterococci (VRE). Biol Pharm Bull. 2007;30(6):1147-9. http:// dx.doi.org/10.1248/bpb.30.1147. PMid:17541170.

13. Savithramma N, Linga Rao M, Suhrulatha D. Screening of Medicinal Plants for Secondary Metabolites. Middle-East J Sci Res. 2011;8(3):579-84.

14. Pandey N, Barve D. Phytochemical and Pharmacological Review on Annona squamosa Linn. J Pharm Biomed Sci. 2011;2(4):1404-12.

15. Mariod AA, Abdelwahab SI, Elkheir S, Ahmed YM, Fauzi PNM, Chuen CS. Antioxidant activity of different parts from Annona squamosa and Catunaregam nilotica methanolic extract. Acta Sci Pol Technol Aliment. 2012;11(3):249-57. PMid:22744945.

16. Borges A, Ferreira C, Saavedra MJ, Simoes M. Antibacterial Activity and mode of action of Ferulic and Gallic Acids against pathogenic bacteria Microb Drug Resist. 2013;19(4):256-65. http://dx.doi.org/10.1089/mdr.2012.0244. PMid:23480526.

17. Arora R, Gill NS, Chauhan G, Rana AC. An overview about versatile molecule capsaicin. Int J Pharm Sci Drug Res. 2011;3:280-6.

18. Yaldiz G, Ozguven M, Sekeroglu N. Variation in capsaicin contents of different capsicum species and lines by varying drying parameters. Ind Crops Prod. 2010;32(3):434-8. http://dx.doi.org/10.1016/j.indcrop.2010.06.013.

19. Topuz A, Ozdemir F. Assessment of carotenoids, capsaicinoids and ascorbic acid composition of some selected pepper cultivars (Capsicum annuum L.) grown in Turkey. J Food Compost Anal. 2007;20(7):596-02. http://dx.doi.org/10.1016/j. jfca.2007.03.007.

20. Ma C, Xiao S, Li Z, Wang W, Du L. Characterization of active phenolic components in the ethanolic extract of Ananas comosus L. leaves using highperformance liquid chromatography with diode array detection and tandem mass spectrometry. J Chromatogr A. 2007;1165(1):39-44. http://dx.doi. org/10.1016/j.chroma.2007.07.060. PMid:17698075 
21. Kalaiselvi M, Gomathi D, Uma C. Occurrence of Bioactive compounds in Ananus comosus (L.): A quality standardization by HPTLC. Asian Pac J Trop Biomed. 2012;2(3):S1341-6. http://dx.doi.org/10.1016/S2221-1691(12)60413-4.

22. Smith BG, Harris PJ. Ferulic acid is esterified to glucuronoarabinoxylans in pineapple cell walls. Phytochemistry. 2001;56(5):513-9. http://dx.doi.org/10.1016/ S0031-9422(00)00401-5.

23. Ou S, Kwok KC. Ferulic acid: pharmaceutical functions, preparation and applications in foods. J. Sci. Food Agr. 2004;84(11):1261-9. http://dx.doi.org/10.1002/ jsfa.1873.

24. National Committee for Clinical Laboratory Standards. Methods for Dilution Anti microbial Susceptibility Tests for Bacteria that Grow Aerobically; Approved Standard-Seventh Edition, CLSI document M7-A7 (ISBN 1-56238-587-9), CLSI, Wayne, Pennsylvania 19087-1898 USA. 2006.
25. Devi KP, Nisha SA, Sakthivel R, Pandian SK. Eugenol (an essential oil of clove) acts as an antibacterial agent against Salmonella typhiby disrupting the cellula membrane. J Ethnopharmacol. 2010;130(1):107-15. http://dx.doi.org/10.1016/j. jep.2010.04.025 PMid:20435121.

26. Zampini IC, Vattuone MA, Isla MI. Antibacterial activity of Zuccagnia punctata Cav. ethanolic extracts. J Ethnopharmacol. 2005;102(3):450-6. http://dx.doi. org/10.1016/j.jep.2005.07.005. PMid:16137849.

27. Wu G, Ding J, Li H, Li L, Zhao R, Fan X, et al. Effects of cations and $\mathrm{pH}$ on antimicrobial activity of thanatin and s-thanatin against Escherichia coli ATCC 25922 and B. subtilis ATCC 21332. Curr Microbiol. 2008;57(6):552-7. http:// dx.doi.org/10.1007/s00284-008-9241-6. PMid:18810542.

28. Burt S. Essential oils: their antibacterial properties and potential applications in foods-a review. Int J Food Microbiol. 2004;94(3):223-53. http://dx.doi. org/10.1016/j.ijfoodmicro.2004.03.022. PMid:15246235.

Cite this article : Nag M, Pulok, Biswas R, Chanda J, Kar A. Evaluation of Antimicrobial Potential of Some Indian Ayurvedic Medicinal Plants. Pharmacognosy Journal. 2016;8(6):525-533. 